\title{
Numerical Taxonomy of Yersinia enterocolitica and Yersinia enterocolitica-Like Bacteria
}

\author{
GEORG KAPPERUD, ${ }^{1,2}$ TOM BERGAN, ${ }^{3}$ AND JØRGEN LASSEN ${ }^{4}$ \\ Zoological Institute, University of Oslo, ${ }^{\prime}$ Norwegian Defense Microbiological Laboratory, ${ }^{2}$ Department of \\ Microbiology, Institute of Pharmacy, University of Oslo, ${ }^{3}$ and National Institute of Public Health, ${ }^{4}$ \\ Oslo, Norway
}

\begin{abstract}
We studied the taxonomic interrelationships of 332 Yersinia strains by using a numerical analysis that was based on 46 cultural and biochemical characters and involved both a hierarchical clustering procedure and a principal components analysis. Yersinia pseudotuberculosis and Yersinia kristensenii were recognized as relatively distinct phenotypic clusters. Y. kristensenii was further distinguishable from the remaining taxa by antigenic and enterotoxigenic parameters. These results supported the suggestion that $Y$. kristensenii deserves species status. On the other hand, Yersinia enterocolitica sensu stricto, Yersinia frederiksenii, and Yersinia intermedia constituted a phenotypic continuum. Each of these three taxa prevailed in different parts of a heterogeneous cluster of strains that were connected by intermediate phenotypes. This pattern of overlapping phenotypes was supported further by antigenic properties, habitat preferences, and pathogenic characteristics. Thus, we failed to find a basis for separating $Y$. enterocolitica sensu stricto, $Y$. frederiksenii, and $Y$. intermedia on phenetic, ecological, or pathogenic grounds. We suggest that the taxonomic relationships among these nomenspecies may require further evaluation. Two phenetic clusters contained strains not ascribable to any presently defined species. One of these clusters consisted mainly of rhamnose-positive, sucrose-negative strains and the other contained strains negative for sucrose or ornithine decarboxylase or both.
\end{abstract}

In Bergey's Manual of Determinative Bacteriology, 8th ed. (12), the genus Yersinia is placed in the family Enterobacteriaceae and contains three recognized species, Yersinia pestis, Yersinia pseudotuberculosis, and Yersinia enterocolitica. Two additional species, Yersinia philomiragia (19) and Yersinia ruckeri (15), have been proposed, but these species have not been accepted generally.

$Y$. enterocolitica as currently recognized is quite heterogeneous, both phenotypically and genetically. A broad diversity of strains are presently placed in this species. The need for a taxonomic revision with a more precise delineation of $Y$. enterocolitica has been recognized $(6$, $8,10,16,21,24,27,33,34,36,39,42,43)$. The designation $Y$. enterocolitica-like bacteria has been applied to atypical variants.

In 1973, Knapp and Thal (27) expressed the opinion that the biochemical diversity of the strains designated $Y$. enterocolitica is sufficient to justify the establishment of two separate species, Y. enterocolitica and "Yersinia enteriti. dis" (names in quotation marks are not on the Approved Lists of Bacterial Names [37] and have not been validly published since January 1, 1980; hence, they are without standing in nomenclature), based on indole production. Jantzen and Lassen (18) examined the fatty acid compositions of $Y$. enterocolitica and $Y$. enterocolitica-like bacteria. The genetic, cultural, and biochemical heterogeneity was not reflected by these fatty acid compositions. This is in accord with the observations of Bercovier and Carlier (3) and Sandhu et al. (K. K. Sandhu, E. J. Bottone, and M. A. Paisano, Abstr. Annu. Meet. Am. Soc. Microbiol. 1980, I54, p. 93). The data per se do not suggest a subdivision of $Y$. enterocolitica as currently recognized.

Brenner (8) and Brenner et al. (10) considered genetic data obtained by deoxyribonucleic acid (DNA)-DNA hybridizations of Yersinia strains. These workers distinguished three DNA relatedness groups among $Y$. enterocolitica and related bacteria, and from the biochemical properties they defined a fourth entity. All groups were referred to the genus Yersinia, but only one deserved the name $Y$. enterocolitica. On the other hand, the genetic data of Moore and Brubaker (34) have suggested that the relationship of $Y$. enterocolitica to the genus Yersinia might require further evaluation. Just recently, Bercovier et al. $(2,4)$, Brenner et al. $(9,11)$, and Ursing et al. (40) described comprehensive stud- 
ies of $175 Y$. enterocolitica and related strains. These authors proposed the following four species, corresponding to distinct DNA relatedness groups: $Y$. enterocolitica sensu stricto (typical isolates), Yersinia frederiksenii (strains producing acid from rhamnose), Yersinia intermedia (strains producing acid from rhamnose and melibiose), and Yersinia kristensenii (strains not producing acid from sucrose).

One important question that needs to be answered is how phenotypic differentiation correlates with genetic subdivision. The numerical taxonomy study of Sakazaki et al. (36), which involved the simple matching coefficient and single-linkage clustering, distinguished four phenotypic clusters, three of which corresponded approximately to the three different DNA relatedness groups described by Brenner et al. (10). However, this clustering procedure is known to be less discriminating. Harvey and Pickett (16) examined 190 strains by using the simple matching coefficient and clustering by unweighted pair group analysis. These authors concluded that the numerical taxonomy relationships did not correlate highly with the results of DNA hybridizations between strains selected from their phenetic clusters. Actually, three strains, including the centrostrain, were selected from each of the main clusters. Two of these did show a good correlation between genetic classification and phenetic classification (namely, the centrostrain and one strain phenetically highly related to the centrostrain). The converse was true for strains distantly related to the centrostrain. This is not unexpected, however, since hierarchical numerical procedures do result in more heterogenous clusters above certain similarity levels as the number of units to be grouped is increased. The validity of groups formed by hierarchical clustering procedures may be assessed by parallel application of several numerical grouping procedures. One efficient method which is supplementary to hierarchical clustering procedures is principal components analysis. This method projects the elements to be classified on twodimensional coordinate plots based on an entirely different computational strategy than phenogram-generating procedures.

The aims of this study were (i) to study the taxonomic interrelationships of $Y$. enterocolitica and $Y$. enterocolitica-like bacteria by a numerical allocation analysis of cultural and biochemical characters, using both a hierarchical clustering procedure and principal components analysis, and (ii) to compare the phenetic relationships indicated by numerical taxonomy with the genetically defined relationships which have been proposed by Bercovier et al. $(2,4)$, Brenner et al. $(9,11)$, and Ursing et al. (40).

\section{MATERIALS AND METHODS}

Bacterial strains. We selected 332 strains belonging to the genus Yersinia for this study (Table 1). These strains were a priori referred to the following categories of Brenner et al. (11).

(i) Y. enterocolitica sensu stricto. A total of 148 strains were typical $Y$. enterocolitica isolates. All produced acid from sucrose but not from melibiose or rhamnose. Seven strains belonging to serogroup 3, biovar 4 (41) were isolated from feces of human patients with gastroenteritis in Norway (strains 32 through 38), and 119 strains were isolated from environmental sources in Scandinavian terrestrial and freshwater ecosystems $(20,21,24,25,28,29)$ (strains 39 through 157). The remaining 22 strains were received as reference strains from the Pasteur Institute, Paris, France (strains 1 through 3, 5 through 15, 20, 21,25 through 29 , and 31 ).

(ii) Y. enterocolitica-like bacteria. A total of 165 strains isolated from Scandinavian environmental sources $(20,21,24,25)$ deviated from the pattern of determinative characteristics typical of $Y$. enterocolitica. These were 51 Y. kristensenii strains that did not produce acid from sucrose (strains 158 through 208), $55 \mathrm{Y}$. frederiksenii strains that produced acid from rhamnose (strains 209 through 263), 25 Y. intermedia strains that produced acid from rhamnose and melibiose (strains 264 through 288 ), and 34 strains which could not be ascribed to any defined species (strains 289 through 322 ). In addition, five reference strains received from the Pasteur Institute, Paris, were classified as members of $Y$. kristensenii (strains 16 through 19 and 30), and four were classified as $Y$. frederiksenii (strains 4 and 22 through 24).

(iii) $Y$. pseudotuberculosis. Seven reference strains representing $Y$. pseudotuberculosis serogroups I through $\mathrm{V}$ were received from $\mathbf{S}$. Winblad, Malmö, Sweden (strains 323 through 329 ).

(iv) Y. pseudotuberculosis-like bacteria. Three strains isolated from wild, small mammals in Denmark (21) exhibited biochemical properties consistent with the properties of $Y$.pseudotuberculosis, but they were antigenically atypical (strains 330 through 332 ).

All strains were maintained as stab cultures on meat extract agar at $4^{\circ} \mathrm{C}$.

Cultural and biochemical determinants. For each strain, 46 cultural and biochemical properties were determined. Incubation was at $37^{\circ} \mathrm{C}$ unless otherwise stated. The tests were read daily for 4 days. Weakly positive or ambiguous tests were incubated further and were read for 7 days.

Acid from carbohydrates. Acidification of carbohydrate-containing media was studied in liquid media containing $0.5 \%$ carbohydrate in $1 \%$ peptone water and $0.0025 \%$ bromothymol blue as an indicator. The basal medium was heat sterilized before the carbohydrates were added. The carbohydrates were sterilized separately by filtration. The media were contained in tubes with cotton plugs.

The following carbohydrates were tested: adonitol, L-arabinose, arbutin, D-cellobiose, dextrin, dulcitol, esculin, D-fructose, D-galactose, glycerol, meso-inositol, inulin, lactose, sodium malonate, maltose, mannitol, D-mannose, D-melibiose, raffinose, L-rhamnose, salicin, D-sorbitol, L-sorbose, starch, sucrose, D-trehalose, 
TABLE 1. List of strains studied

\begin{tabular}{ccc}
\hline Strain no. & Serogroup \\
\hline This study & Other & Source \\
\hline
\end{tabular}

Reference strains of Y. enterocolitica and Y. enterocolitica-like bacteria ${ }^{b}$

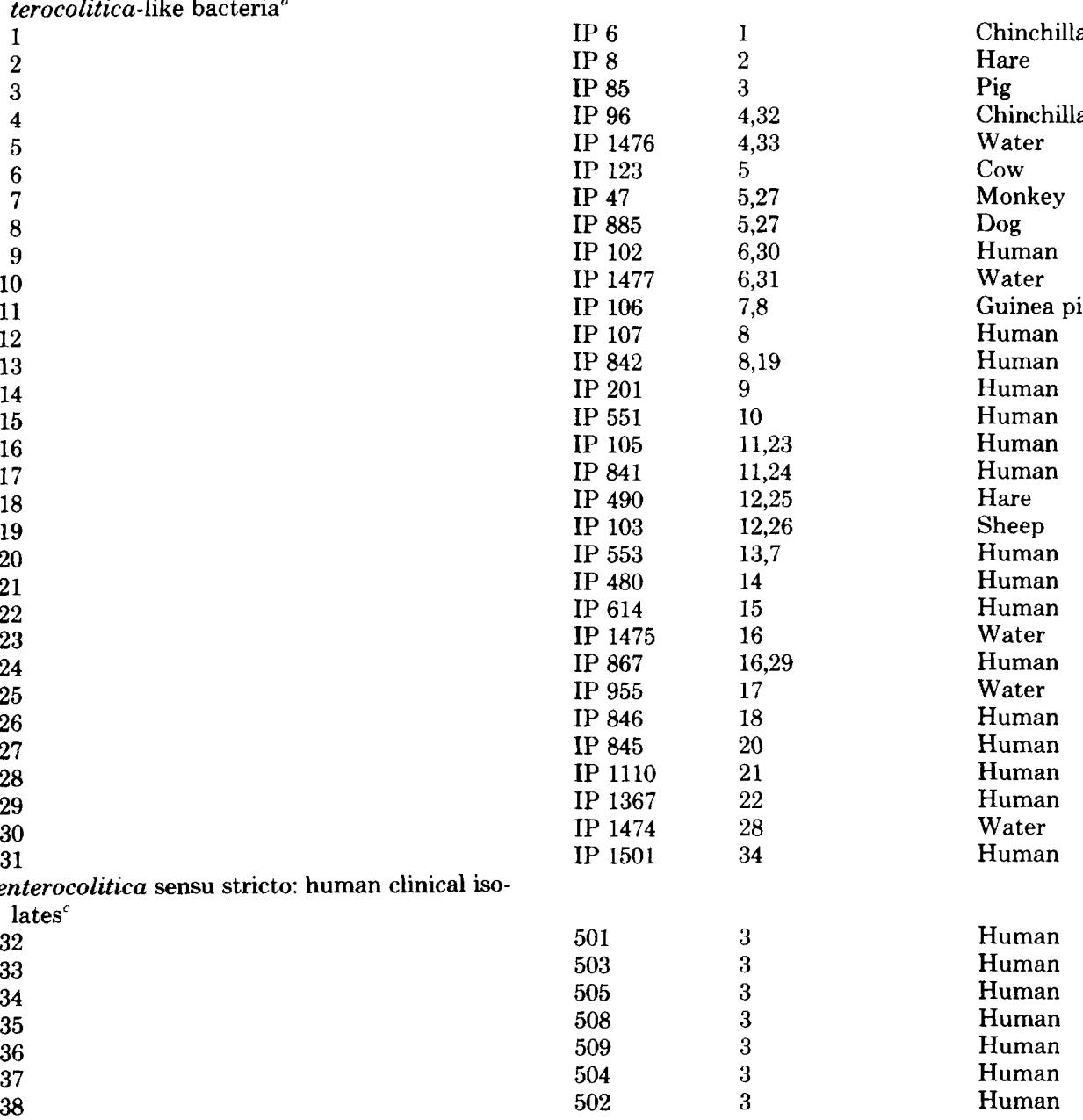

$Y$. enterocolitica sensu stricto: environmental iso-

$\begin{array}{lll}\text { lates } & & \\ 39 & 11046 & 16 \\ 40 & 12027 \mathrm{D} & 7,8 \\ 41 & 12027 \mathrm{~B} & 6 \\ \mathbf{4 2} & 7029 & \text { NAG } \\ 43 & 9028 & \text { NAG } \\ \mathbf{4 4} & 213 & \text { NT } \\ \mathbf{4 5} & \text { N59B } & 13,7 \\ \mathbf{4 6} & 10096 & 4,18,21 \\ \mathbf{4 7} & \mathrm{B} 28 & 14 \\ \mathbf{4 8} & \mathrm{G} 29 \mathrm{~B} & 6 \\ \mathbf{4 9} & \mathrm{G} 27 \mathrm{~A} & 15 \\ 50 & 10016 \mathrm{~A} & 12 \\ 51 & 10047 & 6 \\ 52 & \mathrm{G} 30 \mathrm{~A} & 6 \\ \mathbf{5 3} & \mathbf{\phi 1} & 4 \\ \mathbf{5 4} & 10043 & 6\end{array}$

Small rodent

Small rodent

Small rodent

Small rodent

Small rodent

Water

Fish

Small rodent

Fish

Water

Water

Shrew

Small rodent

Water

Small rodent Small rodent 
TABLE 1-Continued

\begin{tabular}{|c|c|c|c|c|}
\hline \multicolumn{3}{|c|}{ Strain no. } & \multirow{2}{*}{ Serogroup ${ }^{a}$} & \multirow{2}{*}{ Source } \\
\hline & This study & Other & & \\
\hline 55 & & $12025 \mathrm{~A}$ & NAG & Small rodent \\
\hline 56 & & $10012 \mathrm{~A}$ & 6 & Small rodent \\
\hline 57 & & S14 & 16 & Small rodent \\
\hline 58 & & $\phi 2$ & 6 & Small rodent \\
\hline 59 & & V18 & 6 & Small rodent \\
\hline 60 & & V31B & 6 & Small rodent \\
\hline 61 & & $10005 \mathrm{X}$ & NAG & Small rodent \\
\hline 62 & & G6B & 6 & Water \\
\hline 63 & & $5006 \mathrm{~A}$ & NAG & Small rodent \\
\hline 64 & & $\AA 4$ & 1 & Small rodent \\
\hline 65 & & $5006 \mathrm{~B}$ & 6 & Small rodent \\
\hline 66 & & $5003 \mathrm{~B}$ & 4 & Shrew \\
\hline 67 & & $5003 \mathrm{~A}$ & 7,8 & Shrew \\
\hline 68 & & $5010 A$ & 3 & Small rodent \\
\hline 69 & & $10116 \mathrm{C}$ & 6 & Shrew \\
\hline 70 & & G33B & 4 & Water \\
\hline 71 & & 11018 & 4 & Small rodent \\
\hline 72 & & 10129 & 1 & Small rodent \\
\hline 73 & & $\mathrm{R} 21 \mathrm{~A}$ & 6 & Fox \\
\hline 74 & & 11036 & 4 & Small rodent \\
\hline 75 & & 10063 & 3 & Small rodent \\
\hline 76 & & 201 & 5 & Water \\
\hline 77 & & 10143 & 4,16 & Small rodent \\
\hline 78 & & $\mathrm{G} 26 \mathrm{C}$ & 4 & Water \\
\hline 79 & & $1011 \mathrm{~A}$ & 7,8 & Small rodent \\
\hline 80 & & G23A & 4,16 & Water \\
\hline 81 & & R23 & 6 & Fox \\
\hline 82 & & $12013 \mathrm{~A}$ & NAG & Small rodent \\
\hline 83 & & $12013 \mathrm{~B}$ & 16 & Small rodent \\
\hline 84 & & $12025 \mathrm{~B}$ & 6 & Small rodent \\
\hline 85 & & $1005 \mathrm{~B}$ & 12 & Shrew \\
\hline 86 & & 10130 & NAG & Small rodent \\
\hline 87 & & 12001 & 6 & Small rodent \\
\hline 88 & & $1020 \mathrm{~A}$ & 7,8 & Shrew \\
\hline 89 & & 1016 & 6 & Shrew \\
\hline 90 & & $\mathrm{R} 24 \mathrm{~A}$ & 6 & Fox \\
\hline 91 & & 11005 & 3 & Small rodent \\
\hline 92 & & 7021 & 5 & Small rodent \\
\hline 93 & & 7024 & 7,8 & Small rodent \\
\hline 94 & & 7180 & 6 & Small rodent \\
\hline 95 & & S30 & 4 & Small rodent \\
\hline 96 & & $\mathrm{~S} 28$ & 1 & Small rodent \\
\hline 97 & & S18B & NAG & Small rodent \\
\hline 98 & & $\mathrm{~S} 18 \mathrm{C}$ & NAG & Small rodent \\
\hline 99 & & 8018 & 3 & Small rodent \\
\hline 100 & & 8025 & 3 & Small rodent \\
\hline 101 & & S18A & 16 & Small rodent \\
\hline 102 & & B118 & NAG & Fish \\
\hline 103 & & B136B & 4 & Fish \\
\hline 104 & & 10026 & 6 & Small rodent \\
\hline 105 & & G33J & NAG & Water \\
\hline 106 & & $\mathrm{~B} 129 \mathrm{C}$ & 17 & Fish \\
\hline 107 & & 11015 & 1 & Small rodent \\
\hline 108 & & N59A & $\mathrm{NAG}$ & Fish \\
\hline 109 & & G29C & 5 & Water \\
\hline 110 & & 1002 & 6 & Small rodent \\
\hline 111 & & G30B & 17 & Water \\
\hline 112 & & $\mathrm{~B} 123 \mathrm{~A}$ & 14 & Fish \\
\hline 113 & & G33I & 18,IA,IB & Water \\
\hline 114 & & B138A & NAG & Fish \\
\hline
\end{tabular}


TABLE 1-Continued

\begin{tabular}{|c|c|c|c|c|}
\hline \multicolumn{3}{|c|}{ Strain no. } & \multirow{2}{*}{ Serogroup ${ }^{a}$} & \multirow{2}{*}{ Source } \\
\hline & This study & Other & & \\
\hline 115 & & $\mathrm{~N} 10$ & NAG & Fish \\
\hline 116 & & N35B & 4,13 & Fish \\
\hline 117 & & G33H & NAG & Water \\
\hline 118 & & N24A & NAG & Fish \\
\hline 119 & & $\mathrm{~B} 25$ & NAG & Fish \\
\hline 120 & & N55 & IIA & Fish \\
\hline 121 & & G34D & NAG & Water \\
\hline 122 & & B27 & NAG & Fish \\
\hline 123 & & B115 & NAG & Fish \\
\hline 124 & & $\mathrm{G} 33 \mathrm{~F}$ & NAG & Water \\
\hline 125 & & B94 & 16,21 & Fish \\
\hline 126 & & B109 & NAG & Fish \\
\hline 127 & & G23B & 16,22 & Water \\
\hline 128 & & LA37A & NAG & Fish \\
\hline 129 & & N36A & 18,IA,IB & Fish \\
\hline 130 & & $\mathrm{~B} 125$ & NAG & Fish \\
\hline 131 & & B121B & NAG & Fish \\
\hline 132 & & B145 & 14 & Fish \\
\hline 133 & & G33E & NAG & Water \\
\hline 134 & & 11040 & 4 & Small rodent \\
\hline 135 & & $11030 \mathrm{~B}$ & 3 & Small rodent \\
\hline 136 & & 12034 & 6 & Small rodent \\
\hline 137 & & 214 & NT & Water \\
\hline $\begin{array}{l}138 \\
138\end{array}$ & & 217 & NT & Water \\
\hline $\begin{array}{l}100 \\
139\end{array}$ & & 202 & NT & Water \\
\hline 140 & & 208 & 4 & Water \\
\hline 141 & & 212 & NT & Water \\
\hline 142 & & 207 & 4 & Water \\
\hline 143 & & 203 & NT & Water \\
\hline 144 & & 204 & NT & Water \\
\hline 145 & & 218 & NT & Water \\
\hline 146 & & N52 & NAG & Fish \\
\hline 147 & & $\mathrm{~B} 22$ & 16 & Fish \\
\hline 148 & & B123B & 16 & Fish \\
\hline 149 & & $\mathrm{~B} 121 \mathrm{~A}$ & NAG & Fish \\
\hline $\begin{array}{l}140 \\
150\end{array}$ & & 215 & NT & Water \\
\hline 151 & & G17B & 6 & Water \\
\hline 152 & & $\mathrm{~B} 113 \mathrm{~A}$ & NAG & Fish \\
\hline 153 & & $\mathrm{~B} 117 \mathrm{~A}$ & 4,13 & Fish \\
\hline 154 & & $\mathrm{~B} 138 \mathrm{~B}$ & NAG & Fish \\
\hline 155 & & B139 & NAG & Fish \\
\hline 156 & & $\mathrm{~B} 124 \mathrm{~A}$ & 4,13 & Fish \\
\hline 157 & & 2943 & 2 & Goat \\
\hline \multicolumn{5}{|c|}{ Y. enterocolitica-like bacteria: $Y$. kristensenii ${ }^{d}$} \\
\hline 158 & & $11051 \mathrm{~A}$ & 28 & Shrew \\
\hline 159 & & $9019 \mathrm{~A}$ & 28 & Shrew \\
\hline 160 & & $9021 \mathrm{~A}$ & NAG & Shrew \\
\hline 161 & & $1003 \mathrm{~A}$ & 12 & Shrew \\
\hline 162 & & $1015 \mathrm{~A}$ & $\mathrm{NAG}$ & Shrew \\
\hline 163 & & $1015 \mathrm{~B}$ & 12 & Shrew \\
\hline 164 & & G21B & 12 & Water \\
\hline 165 & & 1001 & 28 & Shrew \\
\hline 166 & & $1017 \mathrm{~A}$ & 11 & Shrew \\
\hline 167 & & 1030 & 28 & Small rodent \\
\hline 168 & & G9 & 11 & Water \\
\hline 169 & & $5008 \mathrm{~B}$ & NAG & Small rodent \\
\hline 170 & & $5010 \mathrm{~B}$ & NAG & Small rodent \\
\hline 171 & & G14B & 12 & Water \\
\hline 172 & & 11041 & 12 & Small rodent \\
\hline 173 & & $\mathrm{G} 23 \mathrm{C}$ & NAG & Water \\
\hline
\end{tabular}


TABLE 1-Continued

\begin{tabular}{|c|c|c|c|c|}
\hline \multicolumn{3}{|c|}{ Strain no. } & \multirow{2}{*}{ Serogroup ${ }^{a}$} & \multirow{2}{*}{ Source } \\
\hline & This study & Other & & \\
\hline 174 & & 1018 & NAG & Shrew \\
\hline 175 & & G26D & 12 & Water \\
\hline 176 & & 11047B & 12 & Small rodent \\
\hline 177 & & $1019 B$ & NAG & Shrew \\
\hline 178 & & G2 & 28 & Water \\
\hline 179 & & 9036 & 28 & Small rodent \\
\hline 180 & & $\mathrm{~S} 261$ & NAG & Fish \\
\hline 181 & & 11049 & NAG & Shrew \\
\hline 182 & & S264 & NAG & Fish \\
\hline 183 & & $9021 \mathrm{~B}$ & 28 & Shrew \\
\hline 184 & & 9019B & NAG & Shrew \\
\hline 185 & & 9008 & 28 & Small rodent \\
\hline 186 & & 9020 & 11 & Shrew \\
\hline 187 & & $9017 \mathrm{~A}$ & 11 & Shrew \\
\hline 188 & & $9041 \mathrm{~A}$ & 6 & Small rodent \\
\hline 189 & & $12027 \mathrm{C}$ & 11 & Small rodent \\
\hline 190 & & $12027 \mathrm{~A}$ & NAG & Small rodent \\
\hline 191 & & 12008 & 16 & Small rodent \\
\hline 192 & & G7 & 11 & Water \\
\hline 193 & & G13A & 28 & Water \\
\hline 194 & & G34C & NAG & Water \\
\hline 195 & & $10016 B$ & 28 & Shrew \\
\hline 196 & & G27B & NAG & Water \\
\hline 197 & & $1020 \mathrm{~B}$ & 16 & Shrew \\
\hline 198 & & $1011 \mathrm{C}$ & 16 & Small rodent \\
\hline 199 & & 9017B & NAG & Shrew \\
\hline 200 & & $10012 \mathrm{~B}$ & 16 & Small rodent \\
\hline 201 & & B21A & 1 & Fish \\
\hline 202 & & G26A & NAG & Water \\
\hline 203 & & 8017 & 1 & Small rodent \\
\hline 204 & & $9041 \mathrm{~B}$ & 12 & Small rodent \\
\hline 205 & & 10050 & 1 & Small rodent \\
\hline 206 & & 10053 & 1 & Small rodent \\
\hline 207 & & G14A & 28 & Water \\
\hline 208 & & $11051 B$ & 11 & Shrew \\
\hline \multicolumn{5}{|c|}{ Y. enterocolitica-like bacteria: $Y$. frederiksenii ${ }^{d}$} \\
\hline 209 & & B19 & $4,18,21$, IIB & Fish \\
\hline 210 & & $\mathrm{~B} 16$ & NAG & Fish \\
\hline 211 & & $\mathrm{~B} 21 \mathrm{~B}$ & 17 & Fish \\
\hline 212 & & B30 & NAG & Fish \\
\hline 213 & & B24 & 4 & Fish \\
\hline 214 & & B34 & $4,18,21, \mathrm{IIB}$ & Fish \\
\hline 215 & & G17A & 14 & Water \\
\hline 216 & & G10 & 14 & Water \\
\hline 217 & & 10128 & NAG & Small rodent \\
\hline 218 & & G21A & 17 & Water \\
\hline 219 & & 10139 & 18,21 & Small rodent \\
\hline 220 & & 10140 & 18,21 & Small rodent \\
\hline 221 & & B18 & 17 & Fish \\
\hline 222 & & G19B & 18,21 & Water \\
\hline 223 & & G19a & 4 & Water \\
\hline 224 & & N30 & 14 & Fish \\
\hline 225 & & N47 & IIA & Fish \\
\hline 226 & & G32A & 4 & Water \\
\hline 227 & & $\mathrm{~N} 2$ & 4 & Fish \\
\hline 228 & & N13B & NAG & Fish \\
\hline 229 & & G33D & NAG & Water \\
\hline 230 & & $\mathrm{~N} 42$ & 4,13 & Fish \\
\hline 231 & & N35A & 14 & Fish \\
\hline 232 & & N24B & NAG & Fish \\
\hline
\end{tabular}


TABLE 1-Continued

\begin{tabular}{|c|c|c|c|}
\hline \multicolumn{2}{|r|}{ Strain no. } & \multirow{2}{*}{ Serogroup $^{a}$} & \multirow{2}{*}{ Source } \\
\hline & This study & & \\
\hline 233 & $\mathrm{~N} 40 \mathrm{~B}$ & 4 & Fish \\
\hline 234 & B130B & 4,13 & Fish \\
\hline 235 & $\mathrm{~B} 130 \mathrm{~A}$ & NAG & Fish \\
\hline 236 & N60 & 14 & Bird \\
\hline 237 & N54B & 4,13 & Fish \\
\hline 238 & N13A & NAG & Fish \\
\hline 239 & G18B & $4,16,18,21$ & Water \\
\hline 240 & $\mathrm{~B} 111$ & 4,13 & Fish \\
\hline 241 & B113B & IV & Fish \\
\hline 242 & B106 & NAG & Fish \\
\hline 243 & B97 & 16,21 & Fish \\
\hline 244 & $\mathrm{~B} 123 \mathrm{C}$ & 14 & Fish \\
\hline 245 & B124B & NAG & Fish \\
\hline 256 & B143 & NAG & Fish \\
\hline 247 & N38B & 4,13 & Fish \\
\hline 248 & G33C & NAG & Water \\
\hline 249 & N39 & 4,13 & Fish \\
\hline 250 & N56 & IIA & Fish \\
\hline 251 & N36B & 16 & Fish \\
\hline 252 & 10107 & $4,16,18,21$ & Small rodent \\
\hline 253 & B39 & $4,18,21, \mathrm{IB}, \mathrm{IIB}$ & Fish \\
\hline 254 & $\mathrm{~B} 128 \mathrm{~B}$ & NAG & Fish \\
\hline 255 & G18A & NAG & Water \\
\hline 256 & B131 & NAG & Fish \\
\hline 257 & $\mathrm{~B} 128 \mathrm{~A}$ & 17 & Fish \\
\hline 258 & $\mathrm{~B} 136 \mathrm{~B}$ & 4 & Fish \\
\hline 259 & G34A & 3 & Water \\
\hline 260 & G35A & IV & Water \\
\hline 261 & $\mathrm{~B} 117 \mathrm{~B}$ & 4,13 & Fish \\
\hline 262 & $\mathrm{~B} 102$ & 4 & Fish \\
\hline 263 & B129A & NAG & Fish \\
\hline \multicolumn{4}{|c|}{$Y$. enterocolitica-like bacteria: $Y$. intermedia ${ }^{d}$} \\
\hline 264 & N48 & 13,7 & Fish \\
\hline 265 & B133 & NAG & Fish \\
\hline 266 & N51 & 13,7 & Fish \\
\hline 267 & 10147 & $4,16,18,21$ & Small rodent \\
\hline 268 & 10119 & $4,16,18,21$ & Small rodent \\
\hline 269 & 10098 & $4,16,18,21$ & Small rodent \\
\hline 270 & G19C & NAG & Water \\
\hline 271 & 7174 & 4 & Small rodent \\
\hline 272 & G36A & NAG & Water \\
\hline 273 & F21 & NAG & Fish \\
\hline 274 & N6 & NAG & Fish \\
\hline 275 & N37 & NAG & Fish \\
\hline 276 & B122 & 4 & Fish \\
\hline 277 & LA37B & NAG & Fish \\
\hline 278 & S295B & NAG & Fish \\
\hline 279 & S292A & NAG & Fish \\
\hline 280 & G35B & 4,13 & Water \\
\hline 281 & S292B & NAG & Fish \\
\hline 282 & B38 & NAG & Fish \\
\hline 283 & G32B & NAG & Fish \\
\hline 284 & N23A & NAG & Fish \\
\hline 285 & $\mathrm{~B} 129 \mathrm{~B}$ & 17 & Fish \\
\hline 286 & B126B & NAG & Fish \\
\hline 287 & $\mathrm{~S} 260$ & IIA & Fish \\
\hline 288 & S295A & NAG & Fish \\
\hline \multicolumn{4}{|c|}{ Y. enterocolitica-like bacteria: miscellaneous ${ }^{e}$} \\
\hline 289 & $10005 \mathrm{Y}$ & NAG & Small rodent \\
\hline 290 & G30C & NAG & Water \\
\hline
\end{tabular}


TABLE 1-Continued

\begin{tabular}{|c|c|c|c|c|}
\hline \multicolumn{3}{|c|}{ Strain no. } & \multirow{2}{*}{ Serogroup $^{a}$} & \multirow{2}{*}{ Source } \\
\hline & This study & Other & & \\
\hline 291 & & $\overline{11016}$ & 12 & Small rodent \\
\hline 292 & & G32C & NAG & Water \\
\hline 293 & & 12017 & NAG & Small rodent \\
\hline 294 & & 12020 & NAG & Small rodent \\
\hline 295 & & 12036 & NAG & Small rodent \\
\hline 296 & & 12040 & NAG & Small rodent \\
\hline 297 & & 11050 & 17 & Shrew \\
\hline 298 & & B156 & NAG & Fish \\
\hline 299 & & LA58B & NAG & Fish \\
\hline 300 & & Co26 & NAG & Fish \\
\hline 301 & & LA44A & 13,7 & Fish \\
\hline 302 & & LA58A & NAG & Fish \\
\hline 303 & & $\mathrm{~S} 267 \mathrm{C}$ & 1 & Fish \\
\hline 304 & & $\mathrm{~S} 272$ & NAG & Fish \\
\hline 305 & & G36B & NAG & Water \\
\hline 306 & & G26B & NAG & Water \\
\hline 307 & & G11 & NAG & Water \\
\hline 308 & & 1014 & NAG & Shrew \\
\hline 309 & & $\mathrm{G} 6 \mathrm{~A}$ & NAG & Water \\
\hline 310 & & $\mathrm{R} 21 \mathrm{~B}$ & NAG & Fox \\
\hline 311 & & 10115 & NAG & Small rodent \\
\hline 312 & & $117 \mathrm{~B}$ & NAG & Shrew \\
\hline 313 & & S267A & NAG & Fish \\
\hline 314 & & $\mathrm{~S} 275$ & NAG & Fish \\
\hline 315 & & $\mathrm{~N} 27$ & NAG & Fish \\
\hline 316 & & $1019 \mathrm{~A}$ & NAG & Shrew \\
\hline 317 & & 1004 & NAG & Shrew \\
\hline 318 & & 12012 & $\mathrm{NAG}$ & Shrew \\
\hline 319 & & 10148 & NAG & Small rodent \\
\hline 320 & & $\mathrm{~J} 1$ & NAG & Soil \\
\hline 321 & & N54A & 13,7 & Fish \\
\hline 322 & & 11048 & NAG & Shrew \\
\hline \multicolumn{5}{|c|}{ Y. pseudotuberculosis reference strains ${ }^{f}$} \\
\hline 323 & & 402 & IA & Unknown \\
\hline 324 & & 403 & IB & Unknown \\
\hline 325 & & 407 & IIA & Unknown \\
\hline 326 & & 401 & IIB & Unknown \\
\hline 327 & & 405 & III & Unknown \\
\hline 328 & & 404 & IV & Unknown \\
\hline 329 & & 406 & $\mathrm{~V}$ & Unknown \\
\hline \multicolumn{5}{|c|}{ Y. pseudotuberculosis-like bacteriag } \\
\hline 330 & & $12024 \mathrm{~B}$ & $4,21, \mathrm{IIB}$ & Small rodent \\
\hline 331 & & $12027 \mathrm{E}$ & $4,21, \mathrm{IIB}$ & Small rodent \\
\hline 332 & & 12035 & $4,21, \mathrm{IIB}$ & Small rodent \\
\hline
\end{tabular}

${ }^{a}$ Arabic figures indicate antigenic relationships to serogroups of $Y$. enterocolitica. Roman figures indicate antigenic relationships to serogroups of Y.pseudotuberculosis. NAG, Non-agglutinable; NT, not tested.

${ }^{b}$ The study reported here was completed before the data of Bercovier et al. $(2,4)$, Brenner et al. $(9,11)$, and Ursing et al. (40) were published. Consequently, the type strains proposed by these authors could not be included in this study. The reference strains listed were received from the Pasteur Institute, Paris, as being representative of the taxonomic spectrum consisting of $Y$. enterocolitica and $Y$. enterocolitica-like bacteria.

${ }^{c}$ According to Brenner et al. (11). Serogroup 3, biovar 4 strains (40). These strains were isolated at the National Institute of Public Health, Oslo, Norway, from human patients with gastroenteritis.

${ }^{d}$ According to Brenner et al. (11). These strains were isolated from terrestrial and freshwater ecosystems in Scandinavia $(20,21,24,25,28,29)$.

' These strains were isolated from terrestrial and freshwater ecosystems in Scandanavia $(20,21,24,25,28,29)$ and could not be placed in any presently defined species.

${ }^{\prime}$ Received from S. Winblad, Malmö, Sweden.

${ }^{g}$ These strains were isolated from terrestrial and freshwater ecosystems in Scandanavia $(20,21,24,25,28,29)$ and were biochemically ascribable to $Y$. pseudotuberculosis, but they had atypical antigenic properties $(21,24)$. 
and D-xylose.

The oxidative-fermentative metabolism of lactose was evaluated by the method of Hugh and Leifson (17).

Miscellaneous tests. Acetoin production (VogesProskauer) and methyl red tests were performed in glucose phosphate peptone water (Clark and Lub medium). Acetoin formation was detected by the Barritt method (13); cultures were run in parallel and were incubated at 22 and $37^{\circ} \mathrm{C}$. The ability of the strains to utilize citrate was tested on agar slants of Simmons citrate medium (31). Gelatin hydrolase activity was measured by using photographic film, as described by Le Minor (31). Urease activity and indole production were examined in a combined urea-indole medium, as described by Le Minor (31) and modified at the $\mathrm{Na}$ tional Institute of Public Health, Oslo, Norway (30). Indole was detected by using Kovacs reagent. Motility and nitrate reductase activity were studied by using a combined mannitol-motility medium $(30,31)$. Motility was evaluated after incubation at both 22 and $37^{\circ} \mathrm{C}$. Nitrate reductase activity was tested by adding sulfanilic acid and dimethyl- $\alpha$-naphthylamine (31). The production of gas from glucose and $\mathrm{H}_{2} \mathrm{~S}$ formation were tested in a combined lactose-glucose- $\mathrm{H}_{2} \mathrm{~S}$ medium $(30,31)$. Examination of oxidase activity was by the Kovacs method, in which tetramethyl-p-phenylenediamine dihydrochloride was used. Arginine dihydrolase, lysine decarboxylase, and ornithine decarbox ylase were detected by a method involving modified Falkow medium (31). Lecithinase activity was measured on agar plates containing egg yolk emulsion (type SR 47; Oxoid Ltd., London, England). $\beta$-Galactosidase activity was detected by the $o$-nitrophenyl$\beta$-D-galactopyranoside test described by Le Minor (31).

Numerical procedures. All 46 characters determined were coded in binary form. The two approaches used for numerical analyses of the bacterial strains were as follows.

(i) Hierarchical procedure. The hierarchical clustering procedure was performed by using a program developed at the Norwegian Computing Center, Oslo. This program involves calculating the squared Euclidean distance as a measure of similarity between each pair of strains being grouped (the original numerical units [ONUs]) and subsequent clustering by the Ward procedure (1). This procedure bases successive clusterings on the distances between the centrostrains of individual clusters. The program was constructed to enable efficient handling of a large similarity matrix with a low demand for computer capacity. Each clustering cycle combines ONUs within a narrow range of variance limits. For large similarity matrices, this leads to less detailed differentiation at each clustering cycle compared with the high accuracy achieved by unweighted pair group analysis, in which clustering is based upon exact similarity values between phenons $(5,38)$.

(ii) Principal components analysis. The principal components analysis was performed by using a program which was developed at the Norwegian Computing Center and has been described previously (14). This approach conceives the cultural and biochemical characters as vectors in Euclidean hyperspace and involves calculating the ability of these characters to differentiate between ONUs. To do this, eigenvectors representing the characters are computed, and the variance of each character is calculated on the basis of correlation coefficients. The ONU collection is projected on the principal components as orthogonal coordinates in order of decreasing differentiation between ONUs. The eigenvectors defining the principal components show the relative contribution of every character in defining each component. Thus, the eigenvectors form the basis of an assessment of what bacterial properties contribute most to differentiation among the strains studied.

\section{RESULTS}

Clustering by hierarchical procedure. The results of the hierarchical clustering were represented by a phenogram (Fig. 1). Four main clusters (clusters A through D) were distinguished.

(i) Cluster A. Cluster A could be subdivided into four subclusters (subclusters A1 through A4). All seven Y. pseudotuberculosis reference strains constituted subcluster A1 (strains 323 through 329). Subcluster A2 contained the three Y. pseudotuberculosis-like strains (strains 330 through 332). Subclusters A3 and A4 encompassed $Y$, enterocolitica-like bacteria which could not be placed in any presently defined species. Subcluster A3 consisted of 10 strains, 9 of which produced acid from rhamnose but not from sucrose (strains 289 through 298), and subcluster A4 consisted of 17 strains, most of which were negative for ornithine decarboxylase or sucrose or both (strains 299 through 315 ).

(ii) Cluster B. Cluster B contained 70 strains, 50 of which belonged to Y. kristensenii. Five of these $Y$. kristensenii strains were among the reference strains received from the Pasteur Institute (strains 16 through 19 and 30). The remaining 20 strains in this cluster belonged to $Y$. enterocolitica sensu stricto. Among these 20 strains were all 7 human clinical isolates of serogroup 3, biovar 4 (strains 32 through 38 ) and the two isolates of serogroup 2, biovar 5 (strains 2 and 157) included in this study.

(iii) Cluster C. Cluster $\mathrm{C}$ consisted predominantly of strains of $Y$. enterocolitica sensu stricto. Of the 97 strains in this cluster, 66 were $Y$. enterocolitica sensu stricto, 15 were $Y$. frederiksenii, 10 were $Y$. intermedia, and 2 were $Y$. kristensenii. The remaining four strains were $Y$. enterocolitica-like bacteria which could not be placed in any presently defined species (strains 316 through 319).

(iv) Cluster D. Cluster D was the most heterogeneous of the four main clusters. Of the 128 strains in this cluster, 65 were $Y$. enterocolitica 
sensu stricto, 42 were $Y$. frederiksenii, 15 were $Y$. intermedia, and 3 were $Y$. kristensenii. Three additional strains were $Y$. enterocolitica-like isolates that differed from all previously recognized species (strains 320 through 322 ).

Clustering by principal components analysis. Figure 2 shows the results of the principal components analysis. The 332 Yersinia strains are represented as two-dimensional projections on the first and second principal components (Fig. 2A) and the first and third principal components (Fig. 2B). The clearest separation of the species proposed by Bercovier et al. $(2,4)$, Brenner et al. $(9,11)$, and Ursing et al. (40) was obtained in Fig. 2B. For reference purposes Fig. 2B was subdivided into four quadrants (quadrants QI through QIV).

The strains belonging to phenogram cluster $A$ (Fig. 1) appeared in quadrants QIII and QIV and were reasonably separated from the remaining strains. A tendency tôward subclustering was found with the strains belonging to phenogram subclusters A1 through A4. The subcluster A1, $\mathrm{A} 2$, and $\mathrm{A} 3$ strains were in quadrant QIV. The subcluster A4 strains formed a separate group in quadrant QIII.

Most of the Y. kristensenii strains formed a distinct, relatively tight cluster in quadrant QII, which corresponded approximately to phenogram cluster B. This included the seven human clinical isolates belonging to serogroup 3 , biovar 4. However, the two strains belonging to serogroup 2, biovar 5 were grouped together with the strains of phenogram subcluster A4 in quadrant QIII.

The principal components analysis did not clearly separate $Y$. enterocolitica sensu stricto, $Y$. frederiksenii, and $Y$. intermedia. These strains formed a large, heterogeneous cluster located in quadrant QI and the upper part of quadrant QII, together with a few Y. kristensenii isolates and seven strains which could not be placed in any of the presently defined species (strains 316 through 322 ). This cluster corre-

Fig. 1. Phenogram for 332 Yersinia strains $o b$ tained by hierarchical clustering based on cultural and biochemical determinants. The numbers correspond to the strain numbers in Table 1. Symbols: *, $Y$. pseudotuberculosis reference strains; $\times, Y$. pseudotuberculosis-like bacteria; $O, Y$. enterocolitica sensu stricto; $\Phi, Y$. enterocolitica sensu stricto serogroup 3, biovar 4; $\bigcirc, Y$. enterocolitica sensu stricto serogroup 2, biovar 5;, Y. kristensenii; $\Delta, Y$. frederiksenii; $\Delta, Y$. intermedia; $\mathbf{Q}, Y$. enterocolitica-like bacteria-rhamnose positive and sucrose negative; $\nabla, Y$. enterocolitica-like bacteria-sucrose negative or ornithine decarboxylase negative or both; $\square, Y$. enterocolitica-like bacteria-miscellaneous.

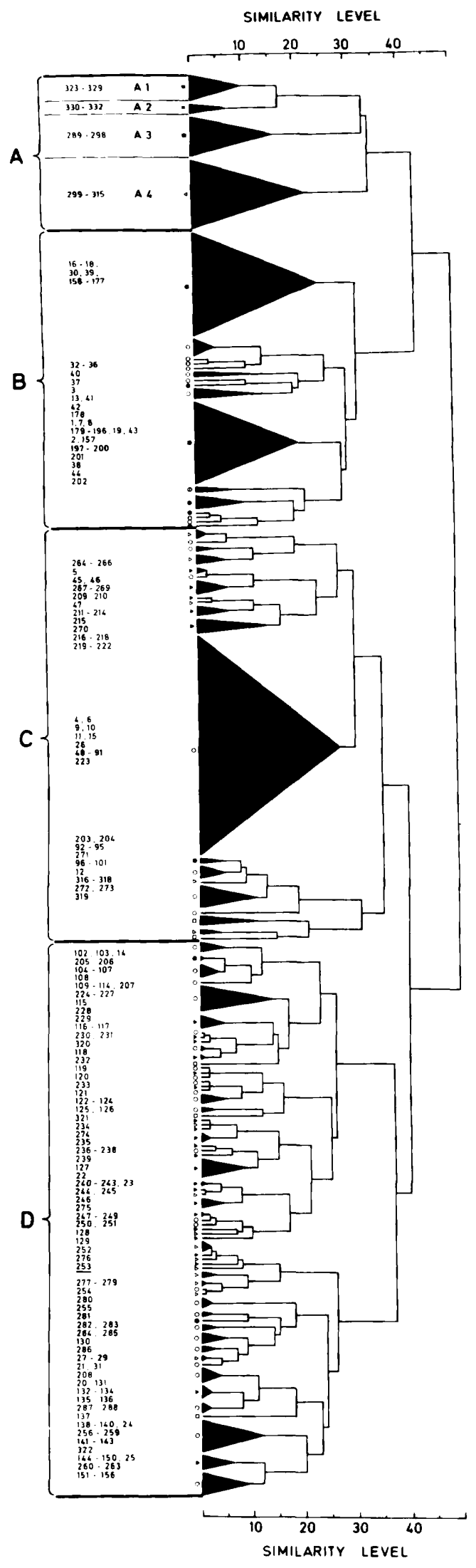


sponded to phenogram clusters $\mathrm{C}$ and $\mathrm{D}$. However, the different taxa were not randomly scattered in this cluster. Strains of Y. enterocolitica sensu stricto dominated the upper part of quad- rant QII and the lower part of quadrant QI, as in phenogram cluster $C$. $Y$. frederiksenii became increasingly more prevalent with increasing distance from quadrant QII, whereas Y. intermedia
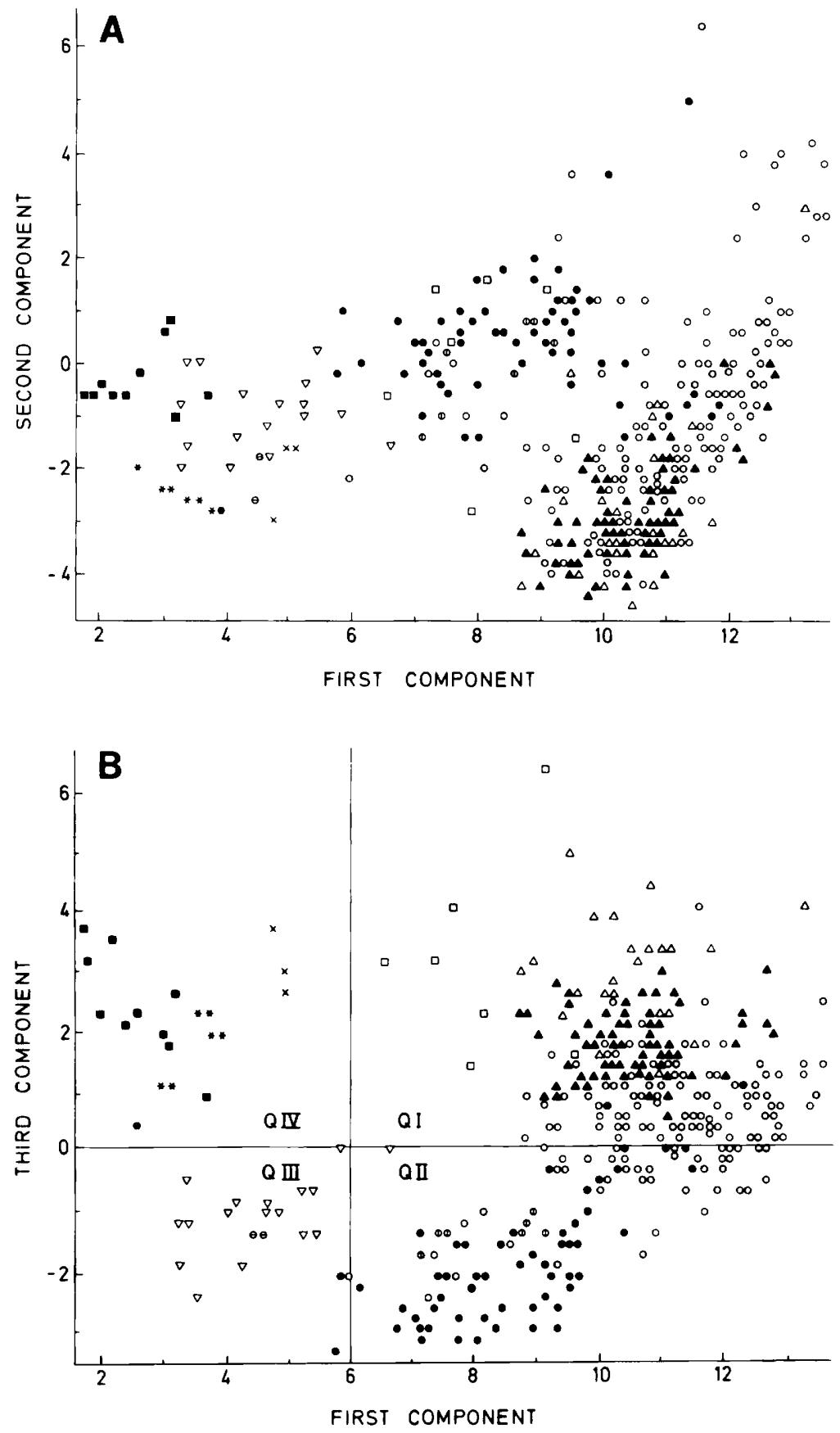

Fig. 2. Principal components analysis. The 332 Yersinia strains are presented in two-dimensional projections on the first and second principal components (A) and the first and third principal components (B) according to their cultural and biochemical properties. For an explanation of the symbols, see the legend to Fig. 1. 
prevailed toward the upper part of quadrant QI (appearing in phenogram cluster D).

Cultural and biochemical characteristics. The cultural and biochemical properties of the main groups are shown in Table 2. The characters shared by all strains included lack of oxidase activity, $\mathrm{H}_{2} \mathrm{~S}$ production, and formation of acid from fructose, malonate, and mannose. With few exceptions, the strains were positive for acid production from arabinose, galactose, maltose, mannitol, and trehalose, for $\beta$-galactosidase, for motility at $22^{\circ} \mathrm{C}$, for the methyl red reaction, for nitrate reductase, and for urease. Furthermore, most strains were negative for acetoin production at $37^{\circ} \mathrm{C}$, for arginine dihydrolase, for gelatin hydrolase, for lysine decarboxylase, and for motility at $37^{\circ} \mathrm{C}$.

Y. kristensenii. Y. kristensenii was defined a priori as those strains which did not produce acid from sucrose. Three additional features distinguished this species. Y. kristensenii was frequently negative for acetoin production at $22^{\circ} \mathrm{C}$ $(86 \%)$, for esculin $(86 \%)$, and, to a lesser degree, for salicin (55\%). High percentages (74 to $100 \%$ ) of the $Y$. enterocolitica sensu stricto, $Y$. freder$i k s e n i i$, and $Y$. intermedia strains were positive for these features.

$Y$. frederiksenii, Y. intermedia, and Y. enterocolitica sensu stricto. The results with $Y$. frederiksenii, $Y$. intermedia, and Y. enterocolitica sensu stricto were tabulated both separately and collectively (Table 2 ) since the numerical analysis did not clearly separate these taxa. $Y$. frederiksenii and $Y$. intermedia seemed to be biochemically more similar to $Y$. enterocolitica sensu stricto than to $Y$. kristensenii. However, except for the production of acid from melibiose, rhamnose, and sucrose, which served to define these species, no further distinction was evident.

Phenogram subclusters A1 and A2. The $Y$. pseudotuberculosis reference strains (subcluster A1) and the $Y$. pseudotuberculosis-like bacteria (subcluster A2) were biochemically similar. All strains produced acid from rhamnose and melibiose (one exception) but not from cellobiose, sorbose, or sucrose; all lacked ornithine decarboxylase.

Phenogram subcluster A3. Of the 10 strains in phenogram subcluster $A 3,9$ produced acid from rhamnose but not from cellobiose, sorbose, or sucrose. All were positive for lysine decarboxylase.

Phenogram subcluster A4. Subcluster A4 consisted of two biochemically different subgroups. A core of eight strains was negative for cellobiose, melibiose, ornithine decarboxylase (six showed delayed reactions), rhamnose, sorbose, and sucrose. The remaining nine strains were positive for sorbitol and sucrose but negative for melibiose (one exception), ornithine decarboxylase (two strains showed delayed reactions), rhamnose, and sorbose; six strains were negative for cellobiose.

Other strains. Seven $Y$. enterocolitica-like bacteria which did not belong to any defined species (strains 316 through 322 ) were distributed between phenogram clusters $\mathrm{C}$ and $\mathrm{D}$ and appeared in quadrant QI in Fig. 2B. These strains constituted a heterogeneous group of strains that were distinguishable from Y. enterocolitica sensu stricto by at least two of the following characters: acid production from melibiose and rhamnose; no acid from cellobiose, sorbose, or sucrose; and absence of ornithine decarboxylase.

Differential characters. The relative contribution of each cultural and biochemical character in defining the first three principal components was derived from the eigenvectors representing each particular principal component. This indicated objectively the relative contributions of the cultural and biochemical properties in differentiating among the strains examined and formed the basis for a rational selection of a minimum set of key properties enabling efficient species identification by routine bacteriology laboratories. The list of key properties derived in this way was compared with the results in Table 2 , and Table 3 shows the characters that differentiate among the main taxa.

Ecology, antigenicity, and pathogenicity factors. The cultural and biochemical characteristics described above formed the basis for taxonomic classification, characterization of taxa, and identification of individual strains. Some of the integral properties of a microorganism are its habitat, pathogenicity, and antigenic specificity. To supplement the description of the four nomenspecies constituting Y. enterocolitica and the $Y$. enterocolitica-like bacteria, the above-mentioned properties are summarized in Table 4. The data are based on Scandinavian isolates included in this and previous studies (20-26, 28, 29).

A majority of the $Y$. kristensenii strains studied belonged to three serogroups (serogroups $0: 11,0: 12$, and $0: 28$ ), which were found only infrequently among the other taxa (24). Y. kristensenii is the only Yersinia species for which enterotoxin production at $37^{\circ} \mathrm{C}$ has been demonstrated at any noticeable frequency (22). Ecologically, $Y$. kristensenii was comparable to $Y$. enterocolitica biovar 1; the highest occurrence of these organisms was among terrestrial vertebrates (24). On the other hand, Y. frederiksenii and $Y$. intermedia were characterized by anti- 
TABLE 2. Cultural and biochemical characteristics of the main taxa

\begin{tabular}{|c|c|c|c|c|c|c|c|c|c|c|}
\hline \multirow[b]{2}{*}{ Character $^{a}$} & \multicolumn{5}{|c|}{$\%$ of positive strains } & \multicolumn{5}{|c|}{ No. of positive strains } \\
\hline & $\begin{array}{l}Y . \text { enter- } \\
\text { ocolitica } \\
(n=148)\end{array}$ & $\begin{array}{c}Y . \text { freder- } \\
\text { iksenii } \\
(n=59)\end{array}$ & $\begin{array}{l}Y . \text { inter } \\
\text { media } \\
(n=25)\end{array}$ & $\begin{array}{l}Y . \text { kris- } \\
\text { tensenii } \\
(n=56)\end{array}$ & $\begin{array}{l}Y . \text { enter- } \\
\text { colitica } \\
\text { plus } Y . \\
\text { frederik- } \\
\text { senii plus } \\
Y . \text { inter- } \\
\text { media } \\
(n=232)\end{array}$ & $\begin{array}{l}Y \text {. enter- } \\
\text { ocolitica } \\
\text { plus } Y \text {. } \\
\text { frederik- } \\
\text { senii } \\
(n=207)\end{array}$ & $\begin{array}{l}\text { Subclus- } \\
\text { ter }^{b} \mathrm{Al} \\
(n=7)\end{array}$ & $\begin{array}{c}\text { Sub- } \\
\text { cluster } \\
\text { A2 } \\
(n=3)\end{array}$ & $\begin{array}{c}\text { Sub- } \\
\text { cluster } \\
\text { A3 } \\
(n=10)\end{array}$ & $\begin{array}{c}\text { Sub- } \\
\text { cluster } \\
\text { A4 } \\
(n=17)\end{array}$ \\
\hline \multicolumn{11}{|l|}{ Acid from: } \\
\hline Adonitol & 18 & 2 & 12 & 14 & 13 & 13 & 0 & 0 & 0 & 1 \\
\hline Arabinose & 99 & 98 & 100 & 98 & 99 & 99 & 5 & 3 & 10 & 16 \\
\hline Arbutin & 95 & 100 & 100 & 88 & 97 & 97 & 7 & 3 & 0 & 0 \\
\hline Cellobiose & 99 & 98 & 96 & 100 & 99 & 99 & 0 & 0 & 0 & 3 \\
\hline Dextrin & 29 & 14 & 28 & 36 & 25 & 25 & 0 & 1 & 0 & 0 \\
\hline Dulcitol & 6 & 0 & 12 & 5 & 5 & 4 & 0 & 0 & 0 & 0 \\
\hline Esculin & 85 & 100 & 100 & 14 & 91 & 89 & 0 & 3 & 1 & 6 \\
\hline Fructose & 100 & 100 & 100 & 100 & 100 & 100 & 7 & 3 & 10 & 17 \\
\hline Galactose & 98 & 100 & 100 & 96 & 99 & 99 & 6 & 3 & 10 & 16 \\
\hline Glycerol & 83 & 64 & 72 & 84 & 77 & 78 & 0 & 3 & 10 & 9 \\
\hline Inositol & 53 & 44 & 64 & 27 & 52 & 51 & 0 & 0 & 0 & 1 \\
\hline Inulin & 14 & 7 & 4 & 5 & 11 & 12 & 0 & 0 & 0 & 0 \\
\hline $\begin{array}{l}\text { Lactose (oxida- } \\
\text { tive) }\end{array}$ & 40 & 36 & 36 & 61 & 38 & 39 & 0 & 0 & 0 & 12 \\
\hline $\begin{array}{l}\text { Lactose (fermen- } \\
\text { tative) }\end{array}$ & 24 & 22 & 48 & 16 & 26 & 24 & 0 & 0 & 0 & 1 \\
\hline Malonate & 0 & 0 & 0 & 0 & 0 & 0 & 0 & 0 & 0 & 0 \\
\hline Maltose & 97 & 100 & 100 & 100 & 98 & 98 & 7 & 3 & 10 & 5 \\
\hline Mannitol & 99 & 98 & 100 & 100 & 99 & 99 & 7 & 3 & 8 & 17 \\
\hline Mannose & 100 & 100 & 100 & 100 & 100 & 100 & 7 & 3 & 10 & 17 \\
\hline Melibiose & 7 & 0 & 100 & 4 & 15 & 5 & 6 & 3 & 3 & 1 \\
\hline Raffinose & 7 & 12 & 36 & 0 & 12 & 9 & 0 & 0 & 2 & 5 \\
\hline Rhamnose & 0 & 100 & 100 & 0 & 38 & 32 & 7 & 3 & 9 & 0 \\
\hline Salicin & 86 & 100 & 100 & 45 & 91 & 90 & 4 & 3 & 0 & 0 \\
\hline Sorbitol & 99 & 100 & 100 & 100 & 99 & 99 & 0 & 0 & 0 & 17 \\
\hline Sorbose & 99 & 92 & 84 & 100 & 95 & 97 & 0 & 0 & 0 & 0 \\
\hline Starch & 44 & 31 & 28 & 68 & 39 & 40 & 0 & 1 & 2 & 1 \\
\hline Sucrose & 100 & 100 & 100 & 0 & 100 & 100 & 0 & 0 & 1 & 9 \\
\hline Trehalose & 99 & 100 & 100 & 100 & 99 & 99 & 7 & 3 & 10 & 17 \\
\hline Xylose & 41 & 20 & 12 & 23 & 33 & 35 & 0 & 0 & 0 & 2 \\
\hline $\begin{array}{l}\text { Acetoin production } \\
\qquad\left(22^{\circ} \mathrm{C}\right)\end{array}$ & 74 & 95 & 92 & 14 & 81 & 80 & 0 & 1 & 10 & 10 \\
\hline $\begin{array}{l}\text { Acetoin production } \\
\qquad\left(37^{\circ} \mathrm{C}\right)\end{array}$ & 1 & 2 & 0 & 0 & 1 & 1 & 0 & 0 & 5 & 0 \\
\hline $\begin{array}{l}\text { Arginine dihydro- } \\
\text { lase }\end{array}$ & 1 & 0 & 0 & 0 & 0 & 0 & 0 & 0 & 0 & 0 \\
\hline Citrate utilization & 1 & 0 & 0 & 9 & 0 & 0 & 0 & 0 & 0 & 0 \\
\hline$\beta$-Galactosidase & 98 & 100 & 100 & 96 & 99 & 99 & 7 & 2 & 6 & 16 \\
\hline Gas from glucose $e^{c}$ & 39 & 34 & 24 & 57 & 36 & 38 & 0 & 0 & 10 & 7 \\
\hline Gelatin hydrolase & 1 & 0 & 0 & 0 & 0 & 0 & 0 & 0 & 0 & 0 \\
\hline $\mathrm{H}_{2} \mathrm{~S}$ production & 0 & 0 & 0 & 0 & 0 & 0 & 0 & 0 & 0 & 0 \\
\hline Indole production & 68 & 73 & 76 & 43 & 70 & 70 & 0 & 0 & 0 & 0 \\
\hline Lecithinase & 52 & 32 & 20 & 20 & 44 & 46 & 0 & 0 & 0 & 0 \\
\hline $\begin{array}{l}\text { Lysine decarboxyl- } \\
\text { ase }\end{array}$ & 2 & 0 & 4 & 2 & 2 & 1 & 0 & 0 & 10 & 1 \\
\hline Methyl red & 100 & 98 & 100 & 100 & 100 & 100 & 7 & 3 & 10 & 17 \\
\hline Motility $\left(22^{\circ} \mathrm{C}\right)$ & 96 & 98 & 100 & 100 & 97 & 97 & 6 & 1 & 10 & 15 \\
\hline Motility $\left(37^{\circ} \mathrm{C}\right)$ & 0 & 2 & 0 & 0 & 0 & 0 & 0 & 0 & 0 & 0 \\
\hline Nitrate reductase & 97 & 100 & 96 & 100 & 98 & 98 & 7 & 3 & 10 & 17 \\
\hline $\begin{array}{l}\text { Ornithine decarbox- } \\
\text { ylase }\end{array}$ & 93 & 92 & 100 & 95 & 93 & 92 & 0 & 0 & 10 & $8^{\prime \prime}$ \\
\hline Oxidase & 0 & 0 & 0 & 0 & 0 & 0 & 0 & 0 & 0 & 0 \\
\hline Urease & 99 & 100 & 100 & 93 & 100 & 100 & 7 & 3 & 9 & 17 \\
\hline
\end{tabular}

"Incubation was at $37^{\circ} \mathrm{C}$ unless otherwise stated.

${ }^{b}$ Subclusters A1 through A4 refer to the phenogram in Fig. 1, as follows: subcluster A1, Y. pseudotuberculosis reference strains; subcluster A2, Y. pseudotuberculosis-like bacteria; subclusters A3 and A4, Y. entercolitica-like bacteria that cannot be placed in any presently defined species.

"Small, but definite amounts of gas were produced.

${ }^{d}$ Delayed reaction (positive after 6 to 7 days). 
TABLE 3. Differential characteristics of the main taxa

\begin{tabular}{|c|c|c|c|c|c|c|c|c|c|c|}
\hline \multirow[b]{2}{*}{$\begin{array}{c}\text { Differential } \\
\text { characteristic }^{a}\end{array}$} & \multicolumn{6}{|c|}{ Reaction of: } & \multicolumn{4}{|c|}{ No. of strains positive/total no. } \\
\hline & $\begin{array}{l}\text { Y. enter- } \\
\text { ocolitica }\end{array}$ & $\begin{array}{l}\text { Y. fred- } \\
\text { eriksenii }\end{array}$ & $\begin{array}{l}Y . \text { inter } \\
\text { media }\end{array}$ & $\begin{array}{l}\text { Y. kris- } \\
\text { tensenii }\end{array}$ & $\begin{array}{l}\text { Y. enter- } \\
\text { ocolitica, } \\
Y . \text { freder- } \\
\text { iksenii, } \\
\text { and Y. in- } \\
\text { termedia } \\
\text { combined }\end{array}$ & $\begin{array}{l}Y . \text { enter- } \\
\text { ocolitica } \\
\text { and } Y . \\
\text { frederik- } \\
\text { senii } \\
\text { combined }\end{array}$ & $\begin{array}{c}\text { Sub- } \\
\text { cluster }^{b} \\
\text { AI }\end{array}$ & $\begin{array}{c}\text { Sub- } \\
\text { cluster } \\
\text { A2 }\end{array}$ & $\begin{array}{l}\text { Subclus- } \\
\text { ter A3 }\end{array}$ & $\begin{array}{l}\text { Subclus- } \\
\text { ter A4 }\end{array}$ \\
\hline Cellobiose & $+c$ & + & + & + & + & + & $0 / 7^{d}$ & $0 / 3$ & $0 / 10$ & $3 / 17$ \\
\hline $\begin{array}{l}\text { Lysine decarbox- } \\
\text { ylase }\end{array}$ & - & - & - & - & - & $\rightarrow$ & $0 / 7$ & $0 / 3$ & $10 / 10$ & $1 / 17$ \\
\hline Melibiose $^{d}$ & - & - & + & - & V & V & $6 / 7$ & $3 / 3$ & $3 / 10$ & $1 / 17$ \\
\hline Rhamnose $^{d}$ & - & + & + & - & V & V & $7 / 7$ & $3 / 3$ & $9 / 10$ & $0 / 17$ \\
\hline Sorbitol & + & + & + & + & + & + & $0 / 7$ & $0 / 3$ & $0 / 10$ & $17 / 17$ \\
\hline Sorbose & + & + & V & + & + & + & $0 / 7$ & $0 / 3$ & $0 / 10$ & $0 / 17$ \\
\hline Sucrose $^{d}$ & + & + & + & - & + & + & $0 / 7$ & $0 / 3$ & $1 / 10$ & $9 / 17$ \\
\hline $\begin{array}{l}\text { Ornithine decar- } \\
\text { boxylase }\end{array}$ & + & + & + & + & + & + & $0 / 7$ & $0 / 3$ & $10 / 10$ & $8 / 17^{e}$ \\
\hline
\end{tabular}

ancubation was at $37^{\circ} \mathrm{C}$.

${ }^{b}$ Subclusters A1 through A4 refer to the phenogram in Fig. 1.

,$+>90 \%$ of the strains positive;,$-<10 \%$ of the strains positive; $\mathrm{V}, 10$ to $90 \%$ of the strains positive.

${ }^{d}$ Characters selected a priori to differentiate $Y$. enterocolitica sensu stricto, $Y$. frederiksenii, Y. intermedia, and $Y$. kristensenii.

'Delayed reaction (positive after 6 to 7 days).

genic, ecological, and pathogenic properties which did not clearly distinguish them from $Y$. enterocolitica sensu stricto. However, it is notable that $Y$. frederiksenii and $Y$. intermedia were ecologically more confined to aquatic ecosystems (fish and water) than Y. enterocolitica sensu stricto, which was prevalent in both terrestrial and aquatic habitats (24). Furthermore, strains of each of these three taxa produced enterotoxin at $22^{\circ} \mathrm{C}$, but this property was rare in Y. frederiksenii and Y. intermedia compared with $Y$. enterocolitica sensu stricto (22). The highest prevalence of enterotoxin production (91\%) was found among human clinical isolates belonging to serogroup 3 , biovar 4 . Invasiveness for HeLa cells was displayed by serogroup 0:3, biovar 4 and serogroup $0: 2$, biovar 5 strains (23), the only recognized pathogens included in Table 4.

\section{DISCUSSION}

Bercovier et al. $(2,4)$, Brenner et al. $(9,11)$, and Ursing et al. (40) divided Y. enterocolitica and Y. enterocolitica-like bacteria into four species by using genotypic parameters. All of these species could be defined phenotypically by using acid production from melibiose, rhamnose, and sucrose as key characters. In our study, this classification was adopted a priori, and the taxonomic relationships of the strains were examined by a numerical clustering analysis based on cultural and biochemical characters. This approach offered an opportunity to compare the genotypically based taxonomy with the phenotypic classification.
Both the principal components analysis and the hierarchical clustering procedure identified Y. kristensenii as a relatively distinct phenotypic cluster (Fig. 1 and 2B). On the other hand, $Y$. enterocolitica sensu stricto, $Y$. frederiksenii, and $Y$. intermedia were grouped together without distinct delineations. These taxa constituted a continuum of intergrading phenotypes. The degree of apparent overlapping between different species depends on and increases with the number of strains included in the study. This is particularly true with dendrogram-generating procedures. Consequently, the principal components analysis is especially important when a large number of organisms are studied. In this procedure, each ONU is positioned more independently in relation to the other strains and more by virtue of its own properties than in dendrograms. Therefore, considerable emphasis must be put on the interpretations of the principal components analysis. The principal components analysis showed that $Y$. enterocolitica sensu stricto and $Y$. frederiksenii overlapped completely (Fig. 2B). Y. intermedia demonstrated a trend toward separation from the $Y$. enterocolitica- $Y$. frederiksenii cluster. However, certain $Y$. intermedia strains were phenetically closely related to the other two nomenspecies. Likewise, a few strains seemed to represent intermediate forms between $Y$. enterocolitica and $Y$. kristensenii. Some sucrose-negative strains were grouped together with $Y$. enterocolitica and vice versa. This observation agrees with the observations of Bercovier et al. (4) and Brenner et al. (11), who reported that the high- 
TABLE 4. Characteristics of Yersinia taxa isolated from environmental and human sources in Scandanavia

\begin{tabular}{|c|c|c|c|c|c|}
\hline Taxon $^{a}$ & Serogroup $(\mathbf{s})^{b}$ & Biovar & Ecological origin $(\mathrm{s})^{d}$ & $\begin{array}{l}\text { Enterotoxin pro- } \\
\text { duction at the fol- } \\
\text { lowing temp }\left({ }^{\circ} \mathrm{C}\right)^{e}\end{array}$ & $\begin{array}{l}\text { Invasive- } \\
\text { ness for } \\
\text { HeLa } \\
\text { cells }^{j}\end{array}$ \\
\hline \multirow{6}{*}{$\begin{array}{l}\text { Y. enterocolitica } \\
\text { sensu stricto }\end{array}$} & 2 & 5 & Goat, gastroenteritis (F) & None ${ }^{g}$ & $+^{*}$ \\
\hline & 3 & 4 & Humans, gastroenteritis (C) & $22(91)$ & + \\
\hline & & 4 & Swine, healthy carriers & $22^{\mu}$ & $+^{g}$ \\
\hline & & 1 & $\begin{array}{l}\text { Mammals, healthy carriers } \\
\text { (F) }\end{array}$ & 22 & \\
\hline & 4,6 , miscellaneous & I & $\begin{array}{l}\text { Mammals, healthy carriers } \\
\text { (C); humans, healthy carriers } \\
\text { (F); birds, healthy carriers } \\
\text { (F); water (F); minced meat } \\
\text { (F) }\end{array}$ & $22(20), 4^{h}$ & - \\
\hline & Miscellaneous & $\mathbf{N}^{i}$ & $\begin{array}{l}\text { Mammals, healthy carriers } \\
\text { (C) fish, healthy carriers }(\mathrm{C}) \text {; } \\
\text { humans, healthy carriers }(\mathrm{F}) \text {; } \\
\text { water }(\mathrm{C})\end{array}$ & $22(20)$ & - \\
\hline Y. kristensensii & $\begin{array}{l}11,12,28, \text { miscella- } \\
\text { neous }\end{array}$ & $\mathrm{N}$ & $\begin{array}{l}\text { Mammals, healthy carriers } \\
\text { (C); fish, healthy carriers }(F) \text {; } \\
\text { humans, healthy carriers (F); } \\
\text { birds, healthy carriers (F); } \\
\text { water (C) }\end{array}$ & 22 and $37(49), 4^{h}$ & - \\
\hline Y. frederiksenii & 4 , miscellaneous & $\mathrm{N}$ & $\begin{array}{l}\text { Fish, healthy carriers (C); } \\
\text { mammals, healthy carriers } \\
\text { (F); humans, healthy carriers } \\
\text { (F); water (C) }\end{array}$ & $22(<5)$ & - \\
\hline$Y$. intermedia & Miscellaneous & $\mathrm{N}$ & $\begin{array}{l}\text { Fish, healthy carriers }(\mathrm{C}) \text {; } \\
\text { mammals, healthy carriers } \\
\text { (F); water (F) }\end{array}$ & $22(<5)$ & - \\
\hline A3 & $\mathrm{NAG}^{\prime}$ & $N$ & $\begin{array}{l}\text { Mammals, healthy carriers } \\
\text { (C); fish, healthy carriers (F); } \\
\text { humans, healthy carriers (F); } \\
\text { water (F) }\end{array}$ & None & - \\
\hline A4 & NAG & $\mathrm{N}$ & $\begin{array}{l}\text { Fish, healthy carriers }(\mathrm{C}) \text {; } \\
\text { mammals, healthy carriers } \\
\text { (F); water }(\mathrm{F})\end{array}$ & None & - \\
\hline
\end{tabular}

${ }^{a}$ Species as proposed by Bercovier et al. $(2,4)$, Brenner et al. $(9,11)$, and Ursing et al. (40). A3 and A4 refer to the phenogram subclusters shown in Fig. 1, as follows: A3, sucrose-negative and rhamnose-positive strains; A4, strains negative for sucrose or ornithine decarboxylase or both.

${ }^{b}$ See references 24,28 , and 29 .

'According to Wauters (41).

${ }^{d}$ See references 24,28 , and 29 . The letters in parentheses indicate the relative importance of each ecological source as a reservoir of the different Yersinia taxa, as follows: C, common; F, a few strains isolated.

${ }^{e}$ See references 22 and 26 . The numbers in parentheses indicate the approximate percentages of enterotoxigenic strains.

' See reference 23 .

${ }^{g}$ Only one strain was examined.

${ }^{h}$ Only 20 strains were examined for enterotoxin production at $4^{\circ} \mathrm{C}(26) ; 3$ of 6 Y. kristensenii strains and 1 of $13 \mathrm{Y}$. enterocolitica sensu stricto strains were positive.

${ }^{i} \mathrm{~N}$, Most strains could not be placed in any of the biovars proposed by Wauters (41).

${ }^{j}$ NAG, Non-agglutinable.

est interspecific DNA relatedness values obtained between these two taxa overlapped the lowest intraspecific values. In contrast to our results, however, $Y$. frederiksenii, $Y$. intermedia, and $Y$. enterocolitica sensu stricto formed distinct DNA relatedness groups. Harvey and Pickett (16) recognized only one DNA related- ness group among rhamnose-positive strains, indicating that the taxonomic positions of $Y$. frederiksenii and $Y$. intermedia may require further evaluation. However, these authors did not mention whether any melibiose-positive strains were represented among their rhamnose-positive isolates. 
The Scandinavian isolates of Y. kristensenii could be distinguished reasonably well from the remaining taxa by antigenic and enterotoxigenic parameters (Table 4). Together with the phenetic distinctness indicated by our work, these observations support the genetic data which suggests that Y. kristensenii deserves separate species status. On the other hand, the pattern of overlapping phenotypes displayed by $Y$. frederiksenii and $Y$. intermedia in relation to $Y$. enterocolitica sensu stricto was supported further by the antigenic properties, habitat preferences, and pathogenic characteristics of these organisms (Table 4). Thus, we failed to find a basis for separating Y. frederiksenii or Y. intermedia from $Y$, enterocolitica sensu stricto on either phenetic, antigenic, ecological, or pathogenic grounds. These observations may have implications for the ability of diagnostic microbiologists to recognize the proposed species, and they question the practical advantage of giving these taxa separate species rank.

The ability to distinguish pathogens from nonpathogens is of considerable practical importance. The typical clinical manifestations of yersiniosis in humans and other animals are associated with only a few distinct serogroup-biovar combinations $(6,32)$. A broad diversity of strains that are antigenically and biochemically distinguishable from the pathogens are omnipresent in nature $(6,24,32)$. Such strains have been isolated occasionally in connection with atypical clinical syndromes $(6,32)$. This has permitted reliable identification of the typical agents of yersiniosis by antigenic and biochemical means. Both Y. intermedia and Y. kristensenii occasionally have been associated with atypical clinical syndromes, but so have various environmental variants of $Y$. enterocolitica sensu stricto $(6$, 32). The clinical distinctiveness of $Y$. intermedia and Y. kristensenii has not been proven yet.

In this present study we included two metabolically inactive. biovar 5 , serogroup 2 clinical isolates. These were strain 2 (IP 8), which was isolated from a hare, and strain 157 , which was obtained from a goat (28). Both of these strains fell outside the $Y$. enterocolitica sensu stricto cluster (Fig. 1 and 2B). Furthermore, the seven human clinical isolates belonging to biovar 4 , serogroup 0:3 were placed in the Y. kristensenii cluster. The conclusion which we drew from this somewhat surprising observation was that these clinical isolates were more related in overall similarity to $Y$. kristensenii than to the bulk of the Y. enterocolitica sensu stricto isolates. However, most of the latter were nonclinical isolates from environmental sources (Table 1). Furthermore, both serogroup 0:2, biovar 5 and sero- group $0: 3$, biovar 4 strains were characterized by ecological and pathogenic properties which clearly distinguished them from all of the remaining taxa examined (Table 4). These observations indicated that the taxonomy of serogroup O:2, biovar 5 and serogroup O:3, biovar 4 strains in relation to the majority of apparently nonpathogenic $Y$. enterocolitica sensu stricto strains prevailing in nature deserves further assessment. On the contrary, these taxa belonged to the same DNA relatedness group (11). Thus, the strict genotypic considerations failed to distinguish the pathogens but did distinguish among $Y$. enterocolitica sensu stricto, $Y$. frederiksenii, and $Y$. intermedia, which is of dubious practical value.

Brenner (8) felt that given a choice between genotypic and phenotypic correctness at the genus level, one may normally choose the phenotypic taxonomy because a taxonomic scheme must be practical (i.e., have identification of strains in mind). However, a classification system which is practical in one context (e.g., medical microbiology) is not necessarily practical in another field (e.g., vertebrate ecology). There is considerable interest in $Y$. enterocolitica and related bacteria in fields other than medical microbiology. Some of these bacteria are ubiquitous in terrestrial and aquatic ecosystems (6, 24,32 ) and may represent adaptations to different habitats (24). The possible wildlife disease implications are not known completely. These circumstances should also be taken into account when a final decision is made concerning the taxonomy of the genus Yersinia.

The phenotypic continuum revealed by the numerical clustering procedures was reflected by the cultural and biochemical data from which the numerical analysis was originally derived (Table 2). Compared with the other taxa, $Y$. kristensenii contained a relatively high percentage of strains negative for acetoin production, esculin, and salicin. Likewise, Y. intermedia contained a high proportion of raffinose-positive strains. However, none of these characters would be useful diagnostically. With the exception of acid production from melibiose, rhamnose, and sucrose, which a priori defined Y. enterocolitica sensu stricto, Y. frederiksenii, Y. intermedia, and Y. kristensenii, none of the cultural or biochemical characters used in this study would serve to differentiate clearly among these taxa (Table 3). Brenner et al. $(9,11)$ used a positive $\alpha$-methyl-D-glucoside reaction and growth on Simmons citrate to distinguish $Y$. intermedia. The former reaction was not tested in our study, and the latter was negative. Furthermore, Bercovier et al. (4) claimed that $Y$. kristensenii did 
not produce acetoin, but we found that $14 \%$ of the $Y$. kristensenii strains which we studied produced this compound.

However, we should note that most of the cultural and biochemical observations of Brenner and his co-workers were based on incubations at $28^{\circ} \mathrm{C}$, in contrast to our incubation temperature of $37^{\circ} \mathrm{C}$. We chose this incubation temperature to be in accord with standard methods used in medical microbiology. Certain cultural and biochemical properties of $Y$. enterocolitica and related bacteria display a pronounced temperature dependency; generally, the properties are negative at $37^{\circ} \mathrm{C}$ and positive at incubation temperatures lower than $30^{\circ} \mathrm{C}(6,35,41)$. At present, however, we have no reason to suggest that phenotypic data obtained at lower temperatures are better indicators of underlying genetic differences. Harvey and Pickett (16) argued that incubation temperature is a critical factor in determining the relative arrangement of Yersinia strains within phenograms generated by hierarchical clustering. More work will be needed to determine whether numerical classification systems based on phenotypic expressions at lower temperatures reflect the reported genetic discontinuities between $Y$. enterocolitica sensu stricto and related species.

Another factor which may influence taxonomic interpretations is the particular collection of strains selected for a taxonomic study. Thus, the incomplete separation of $Y$. enterocolitica sensu stricto, $Y$. frederiksenii, and $Y$. intermedia in this work may be attributable to the broad ecological range covered by our strains. Most of these strains were isolated from nonhuman, nonclinical sources from Scandinavian terrestrial and aquatic ecosystems, representing numerous microhabitats $(20,21,24,25,29)$. When such a broad range of related habitats is examined, a corresponding spectrum of intermediate strains spanning the gaps between clusters of markedly distinct phenotypes may result. The limited number of habitats traditionally examined for routine diagnostic purposes by medical microbiologists predominantly uncover strains adapted to these habitats and do not represent the complete ecological ranges of these bacteria. This may give a false impression of discontinuous taxa. Clinical isolates were more prevalent among the strains investigated by Brenner and co-workers $(2,4,9,11,40)$ than in our study. In addition, their strains represented a very broad geographic range. This also might have contributed to dissimilar taxonomic interpretations. Ideally, a taxonomic scheme should allow a classification of strains representing the total ecological and geographic ranges.
Bercovier et al. $(2,4)$, Brenner et al. $(9,11)$, and Ursing et al. (40) used a suitable technique to study the genetic relationships among Yersinia strains and thereby have contributed considerably to an understanding of the taxonomy of this bacterial group. The studies of these authors were prompted by the phenotypic heterogeneity in $Y$. enterocolitica and related bacteria. First, the strains were grouped on the basis of biochemical parameters, and then these biochemical groups were tested for intra- and intergroup DNA relatedness by using one or two strains from each group as a source of reference DNA. These workers concluded that most of the phenotypic groups defined a priori formed distinct genotypic clusters. However, the reported differences in intragroup DNA relatedness values might indicate that selection of a different set of reference DNAs and inclusion of more diverse strain material could have resulted in a higher degree of overlap between intra- and intergroup DNA relatedness. It may be that selection of only one or two reference DNAs from each of the proposed species constitutes too narrow a basis for formal assessment of genetic diversity within the genus Yersinia. At present, we would tend to be a little restrained in accepting the clear genetic discontinuities documented as necessarily justifying a taxonomic subdivision since the degree of genetic overlap has not been clarified fully. Our data indicate that the subdivision may be pending and that the distinctions among $Y$. enterocolitica sensu stricto and the related nomenspecies have not been resolved yet.

In this work we distinguished two phenotypic clusters that could not be placed in any recognized species (phenogram subclusters A3 and A4) (Fig. 1). Subcluster A3 consisted mainly of strains which were positive for lysine decarboxylase and rhamnose but negative for cellobiose, sorbose, and sucrose (Table 3). Knapp and Thal (27) were the first to suggest that rhamnosepositive, sucrose-negative strains did not belong to $Y$. enterocolitica. A DNA relatedness group containing rhamnose-positive, sucrose-negative strains was recognized by Harvey and Pickett (16). Likewise, Brenner et al. (11) distinguished a DNA relatedness group with biochemical properties corresponding approximately to the properties of subcluster A3; they designated this group Yersinia biotype X2. However, subcluster A3 strains differed from biotype X2 strains by being negative for citrate utilization (Simmons) and acid production from sorbitol. These differences may be attributable to the dissimilar incubation temperatures used (see above). All strains in subcluster A3 were positive for lysine decarboxylase and maltose. The presence of ly- 
sine decarboxylase is typical of $Y$. ruckeri, one of the agents of red-mouth disease in trout and salmon $(8,15)$. Subcluster A3 strains differed from Y. ruckeri by being positive for rhamnose, urease, and acetoin production (Table 2).

Subcluster A4 included eight strains that were negative for ornithine decarboxylase and sucrose. This group corresponded approximately to Yersinia biotype $\mathrm{X} 1$, a distinct DNA relatedness group recognized by Brenner et al. (11). The eight subcluster A4 strains differed from biotype $\mathrm{X} 1$ strains by being positive for sorbitol and occasionally producing acetoin.

The remaining nine subcluster A4 strains were positive for sorbitol and sucrose but negative for melibiose (one exception), ornithine decarboxylase (two showed delayed reactions), rhamnose, and sorbose. Similar strains have not been distinguished by DNA hybridization studies.

Subclusters A3 and A4 strains seem to have different ecological properties, occurring most frequently in terrestrial and aquatic ecosystems, respectively (Table 4). Enterotoxin production was not detected in these strains. However, a study of a more extensive collection of strains will be necessary to allow definite conclusions concerning the ecology and enterotoxigenicity of subclusters A3 and A4 strains.

Phenotypically, both subcluster A3 and subcluster A4 formed relatively distinct groups (Fig. 1 and $2 \mathrm{~B}$ ). Both seemed more similar to $Y$. pseudotuberculosis than to $Y$. enterocolitica sensu stricto, but further work will be needed to evaluate the taxonomic rank of these taxa.

The three Y. pseudotuberculosis-like isolates (strains 330 through 332) were phenetically closely related to the Y. pseudotuberculosis reference strains (Fig. 1 and 2). All were invasive for HeLa cells (23), which is a recognized feature of $Y$. pseudotuberculosis (7). We suggest that these strains should be classified as antigenically atypical variants within this species.

\section{REPRINT REQUESTS}

Address reprint requests to: Georg Kapperud, Norwegian Defense Microbiological Laboratory, National Institute of Public Health, Geitmyrsveien 75, Oslo 4, Norway.

\section{LITERATURE CITED}

1. Anderberg, M. R. 1973. Cluster analysis for applications. Academic Press, Inc., London.

2. Bercovier, H., D. J. Brenner, J. Ursing, A. G. Steigerwalt, G. R. Fanning, J. M. Alonso, G. A. Carter, and H. H. Mollaret. 1980. Characterization of Yersinia enterocolitica sensu stricto. Curr. Microbiol. 4:201-206.

3. Bercovier, H., and J. P. Carlier, 1979. Chromatographie en phase gazeuse des acides gras fixes produits par Yersinia enterocolitica dans divers milieux liquides. Ann. Microbiol. (Paris) 130A:37-46.

4. Bercovier, H., J. Ursing, D. J. Brenner, A. G. Steigerwalt, G. R. Fanning, G. P. Carter, and H. H.
Mollaret. 1980. Yersinia kristensenii: a new species of Enterobacteriaceae composed of sucrose-negative strains (formely called atypical Yersinia enterocolitica or Yersinia enterocolitica-like). Curr. Microbiol. 4:219224.

5. Bergan, T. 1971. Survey of numerical techniques for grouping. Bacteriol. Rev. 35:379-389.

6. Bottone, E. J. 1977. Yersinia enterocolitica: a panoramic view of a charismatic microorganism. Crit. Rev. Microbiol. 5:211-241.

7. Bovallius, A., and G. Nilsson. 1975. Ingestion and survival of Yersinia pseudotuberculosis in HeLa cells. Can. J. Microbiol. 21:1977-2007.

8. Brenner, D. J. 1979. Speciation in Yersinia. Contrib. Microbiol. Immunol. 5:33-43.

9. Brenner, D. J., H. Bercovier, J. Ursing, J. M. Alonso, A. G. Steigerwalt, G. R. Fanning, G. P. Carter, and H. H. Mollaret. 1980. Yersinia intermedia: a new species of Enterobacteriaceae composed of rhamnosepositive, melibiose-positive, raffinose-positive strains (formerly called Yersinia enterocolitica or Yersinia enterocolitica-like). Curr. Microbiol. 4:207-212

10. Brenner, D. J., A. G. Steigerwalt, D. P. Falcao, R. E. Weaver, and G. R. Fanning. 1976. Characterization of Yersinia enterocolitica and Yersinia pseudotuber. culosis by deoxyribonucleic acid hybridization and by biochemical reactions. Int. J. Syst. Bacteriol. 26:180194.

11. Brenner, D. J., J. Ursing, H. Bercovier, A. G. Steigerwalt, G. R. Fanning, J. M. Alonso, and H. H. Mollaret. 1980. Deoxyribonucleic acid relatedness in Yersinia enterocolitica and Yersinia enterocoliticalike organisms. Curr. Microbiol. 4:195-200.

12. Buchanan, R. E., and N. E. Gibbons (ed.). 1974. Bergey's manual of determinative bacteriology, 8 th ed. The Williams \& Wilkins Co., Baltimore.

13. Cruickshank, R., J. P. Duguid, B. P. Marmion, and R. H. A. Swain. 1975. Medical microbiology, vol. 2. The practice of medical microbiology, 12th ed. Churchill Livingstone, Edinburgh.

14. Dixon, W. J. (ed.). 1965. BMD biomedical computer programs. Health Sciences Computing Facility, University of California, Los Angeles.

15. Ewing, W. H., A. J. Ross, D. J. Brenner, and G. R. Fanning. 1978. Yersinia ruckeri sp. nov., the redmouth (RM) bacterium. Int. J. Syst. Bacteriol. 28:37-44.

16. Harvey, S., and M. J. Pickett. 1980. Comparison of Adansonian analysis and deoxyribonucleic acid hybridization results in the taxonomy of Yersinia enterocolit. ica. Int. J. Syst. Bacteriol. 30:86-102.

17. Hugh, R., and E. Leifson. 1953. The taxonomic significance of fermentative versus oxidative metabolism of carbohydrates by various gram-negative bacteria. J. Bacteriol. 66:24-26.

i8. Jantzen, E., and J. Lassen. 1980. Characterization of Yersinia species by analysis of whole-cell fatty acids. Int. J. Syst. Bacteriol. 30:421 -428 .

19. Jensen, W. I., C. R. Owen, and W. L. Jellison. 1969. Yersinia philomiragia sp. n., a new member of the Pasteurella group of bacteria, naturally pathogenic for the muskrat (Ondatra zibethica). J. Bacteriol. 100: 1237-1241.

20. Kapperud, G. 1975. Yersinia enterocolitica in small rodents from Norway, Sweden and Finland. Acta Pathol. Microbiol. Scand. Sect. B 83:335-342.

21. Kapperud, G. 1977. Yersinia enterocolitica and Yersinia-like microbes isolated from mammals and water in Norway and Denmark. Acta Pathol. Microbiol. Scand. Sect. B 85:129-135.

22. Kapperud, G. 1980. Studies on the pathogenicity of Yersinia enterocolitica and $Y$. enterocolitica-like bacteria. I. Enterotoxin production at $22^{\circ} \mathrm{C}$ and $37^{\circ} \mathrm{C}$ by environ- 
mental and human isolates from Scandinavia. Acta Pathol. Microbiol. Scand. Sect. B 88:287-291.

23. Kapperud, G. 1980. Studies on the pathogenicity of Yer. sinia enterocolitica and $Y$. enterocolitica-like bacteria. II. Interaction with HeLa cells among environmental and human isolates from Scandinavia. Acta Pathol. Microbiol. Scand. Sect. B 88:293-297.

24. Kapperud, G. 1981. Survey on the reservoirs of Yersinia enterocolitica and Yersinia enterocolitica-like bacteria in Scandinavia. Acta Pathol. Microbiol. Scand. Sect. B. 89:29-35.

25. Kapperud, G., and B. Jonsson. 1978. Yersinia enter ocolitica et bactéries apparentées isolées à partir d'écosystèmes d'eau douce en Norvége. Med. Mal. Infect. 8:500-506.

26. Kapperud, G., and G. Langeland. 1981. Enterotoxin production at refrigeration temperature by Yersinia enterocolitica and Y. enterocolitica-like bacteria. Curr. Microbiol. 5:119-122.

27. Knapp, W., and E. Thal. 1973. Differentiation of Yersinia enterocolitica by biochemical reactions. Contrib. Microbiol. Immunol. 2:10-16.

28. Krogstad, 0. 1974. Yersinia enterocolitica infection in goat. A serological and bacteriological investigation. Acta Vet. Scand. 15:597-608.

29. Lassen, J. 1972. Yersinia enterocolitica in drinking-water. Scand. J. Infect. Dis. 4:125-127.

30. Lassen, J. 1975. Rapid identification of gram-negative rods using a three-tube method combined with a dichotomic key. Acta Pathol. Microbiol. Scand. Sect. B 83: 525-533.

31. Le Minor, L. 1967. Le diagnostic de laboratoire des entérobactéries, 3rd ed. Éditions de la Tourelle, St. Mandé, France.

32. Mollaret, H. H., H. Bercovier, and J. M. Alonso. 1979. Summary of the data received at the WHO Reference Center for Yersinia enterocolitica. Contrib. Microbiol. Immunol. 5:174-184.

33. Mollaret, H. H., and W. Knapp. 1972. International Committee on Systematic Bacteriology Subcommittee on the Taxonomy of Pasteurella, Yersinia, and Francisella. Minutes of the meeting, 13 April 1972. Int. J. Syst. Bacteriol. 22:401.

34. Moore, R. L., and R. R. Brubaker. 1975. Hybridization of deoxyribonucleotide sequences of Yersinia enteroco. litica and other selected members of Enterobacteriaceae. Int. J. Syst. Bacteriol. 25:336-339.

35. Niléhn, B. 1969. Studies on Yersinia enterocolitica with special reference to bacterial diagnosis and occurrence in human acute enteric disease. Acta Pathol. Microbiol. Scand. Suppl. 206:1-48.

36. Sakazaki, R., K. Tamura, and T. Shimada. 1979. Numerical classification of Yersinia enterocolitica and relationship between its subdivision and pathogenicity. Contrib. Microbiol. Immunol. 5:23-32.

37. Skerman, V. B. D., V. McGowan, and P. H. A. Sneath (ed.). 1980. Approved lists of bacterial names. Int. J. Syst. Bacteriol. 30:225-420.

38. Sneath, P. H. A., and R. R. Sokal. 1973. Numerical taxonomy. The principles and practice of numerical classification. W. H. Freeman and Co., San Francisco.

39. Stevens, M., and N. S. Mair. 1973. A numerical taxonomic study of Yersinia enterocolitica strains. Contrib. Microbiol. Immunol. 2:17-22.

40. Ursing, J., D. J. Brenner, H. Bercovier, G. R. Fanning, A. G. Steigerwalt, J. Brault, and H. H. Mollaret. 1980. Yersinia frederiksenii: a new species of Enterobacteriaceae composed of rhamnose-positive strains (formerly called atypical Yersinia enterocolitica or Yersinia enterocolitica-like). Curr. Microbiol. 4:213217.

41. Wauters, G. 1970. Contribution a l'étude de Yersinia enterocolitica. Thèse d'Agrégation, Louvain. Vander, Brussels.

42. Wauters, G. 1973. Correlation between ecology, biochemical behaviour and antigenic properties of Yersinia enterocolitica. Contrib. Microbiol. Immunol. 2:38-41.

43. Winblad, S. 1979. Differentiation of Yersinia enteroco. litica strains in subgroups after biochemistry and serology. Contrib. Microbiol. Immunol. 5:44-49. 